
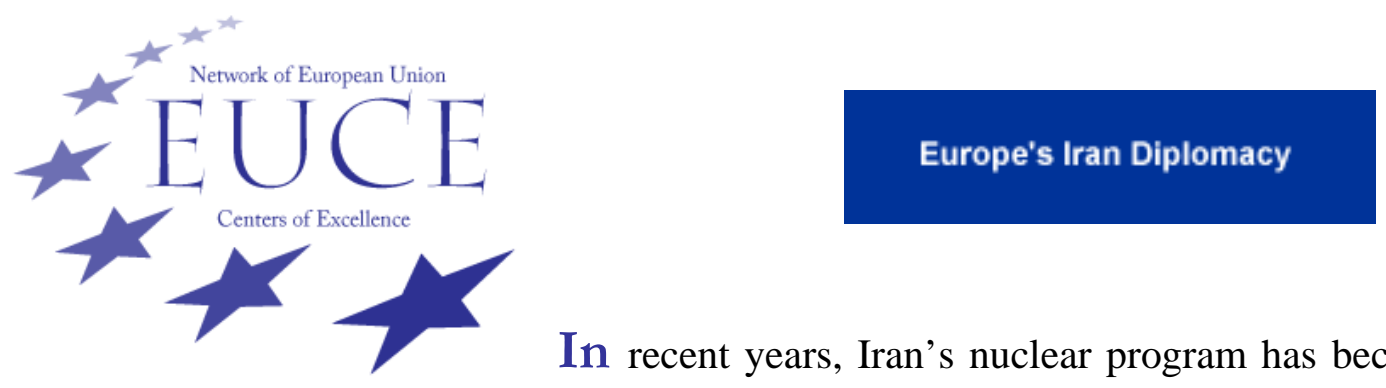

In recent years, Iran's nuclear program has become an issue of major concern to Europe and the United States. Iran insists that its nuclear program is aimed solely at producing peaceful nuclear energy. Many observers on both sides of the Atlantic, however, suspect with good reason that Iran is trying to develop nuclear weapons. Neither the United States nor Europe can countenance Iran possessing a nuclear bomb. But how can Europe and America ensure that Iran's weapons program remains peaceful? There is no obvious answer. Iran is in an unusually strong position, as high oil prices give it substantial power over the world economy. Meanwhile, the United States is tied down in an ongoing war in Iraq that weakens its capacity for a military component to its diplomatic action.

In Iraq, the United States took an extremely aggressive approach to the possible threat of Iraqi weapons of mass destruction, ultimately alienating some key NATO allies. In the case of Iran, European led transatlantic diplomacy since mid-2003 has contrasted markedly with the Iraq experience. Whereas the United States pressed for immediate punitive action against Iran, Europe was favored a policy of "critical dialogue" that has emphasized what Iran had to gain by eschewing nuclear weapons. This brief explains the logic, history, and results of the European strategy.

\title{
The Stakes
}

Iran is a country of substantial importance to the United States and Europe alike. U.S. and European relations with Iran have been poor since the Iranian revolution of 1979 replaced the American supported Shah with an Islamist theocracy. Since the end of the Cold War, Iran has frequently clashed with Europe and the U.S. on a variety of topics. Thus, the west has criticized Iran for its frequent disregard for human rights, its support for proscribed terrorist groups like Hezbollah and Hamas, its enmity towards Israel and its fatwa against British novelist Salman Rushdie. Iran, on the other hand, has for long remained suspicious of the involvement of western powers in its internal affairs; remembering only too well that its first democratically-elected government was overthrown with the assistance of western security agencies in 1953 and that the West covertly supported Saddam Hussein during the Iran-Iraq War in the 1980s. Moreover, with the US-led invasions of Afghanistan and Iraq in 2001 and 2003, Iran now feels itself encircled and under threat, although this has been overstated to the advantage of the Iranian regime.

Since 2003, however, the issue of greatest contention between Iran and the Western powers has been Iran's nuclear program. While the exact purpose of Iran's nuclear program remains open to speculation, most western analysts agree that the consequences

The European Union Center of Excellence of the University of North Carolina at Chapel Hill is funded by the European Union to advance knowledge and understanding of the EU and its member countries. 
of Iran developing a nuclear bomb would be serious. Some fear that if Iran were to gain nuclear weapons they could easily fall into the hands of terrorist groups, although the consequences for Iran as the originating country would be too severe to make this a rational option for them. Others have argued that a nuclear Iran would set of a proliferation-spiral in the Middle East turning this critical region into a tinderbox. Further development of an Iranian bomb could also invite a pre-emptive Israeli attack on Iran or even draw the U.S. itself into a dangerous new conflict, at a time when its armed forces are over-stretched. The fact that Iran is a traditional enemy of Iraq, now under American control, only complicates the situation further. Finally, there is the broader issue of weapons proliferation itself. If Iran gains entry into the "nuclear club", some fear this might further undermine the global anti-proliferation regime, opening the door to nuclear aspirants all over the globe, although the containment of the AQ Khan network has dramatically reduced the numbers of opportunities for proliferating countries.

\section{The Recent Evolution of Iran's Relations with the West}

Since its revolution Iran has been an Islamic Republic, governed mainly by its Shiite religious elite. After the Revolution, Iran departed on a course combining a closure of its country to western influence with the attempt to export the Islamic Revolution to other Middle Eastern countries. Following the end of the Iran-Iraq War and the death of Ayatollah Khomeini, however, Iran appeared to be shifting slowly toward a somewhat more open attitude concerning relations with the West. Under the leadership of the moderate Rafsanjani, Iran engaged in a process of economic and diplomatic rapprochement. The EU sought to deepen this process by engaging in a "critical dialog" with Iran in 1992. At the time, there existed a general consensus in Europe that Iran was tending towards moderation and that the human-rights focused "critical dialog" could play a role in deepening this process.

The US on the other hand maintained the view that Iran could only be changed through pressure and sanctions and in 1995 the Clinton administration passed the so-called D'Amato bill (ILSA) of economic sanctions. Europe refused to follow this lead and rejected the imposition of sanctions on Iran. As a result there were frequent transatlantic dissonances over how to approach this strategically important country. At the same time, European trade-ties with Iran further deepened during this period. Still in early 1997 EUIran relations were seriously damaged as a result of the Mykonos Trial, when it emerged that the Iranian government had been directly involved in the assassination of Iranian opposition figures in Europe in the early 1990s. However, the election of the Reformist President Mohammed Khatami later the same year led to a quick revival of EU-Iranian relations. Europe's critical dialogue was replaced with a new "comprehensive dialogue" including a host of issues such as non-proliferation, human rights and the Middle East peace process.

In the aftermath of the 9/11 attacks Western relations with Iran experienced a brief peak. Against all odds, Iran remained supportive of the US-led invasion of Afghanistan and Iranian President Khatami even offered a "dialogue of civilizations" with the West,

The European Union Center of Excellence of the University of North Carolina at Chapel Hill is funded by the European Union to advance knowledge and understanding of the EU and its member countries. 
including the United States. At the time, the offer was disregarded by the U.S. and is still seen as a missed opportunity. Still the positive trend in European-Iranian relations continued unabated in 2002, when Iran and the EU decided to begin negotiations for a far reaching Trade and Cooperation Agreement (TCA). Bilateral relations between Europe and Iran, however, started to worsen in the course of 2002, when the Iranian reformist movement was increasingly challenged by a resurgent wave of conservatism. Indeed, 2002 turned into a watershed year, as news of Iran's nuclear program emerged, leading to the suspension of the comprehensive dialogue the following year. Relations between Iran and the US only worsened, when the Bush administration labeled Iran part of the "Axis of Evil” along with Iraq and North Korea. Needless to say, neither the Clinton nor Bush Administration restored diplomatic ties.

\section{The Failure of EU Incentives}

The crisis over Iran's nuclear program began in mid-2002, when news of two previously unknown nuclear facilities emerged - an uranium enrichment facility at Natanz and a heavy water production plant at Arak. The crisis deepened in 2003 when the International Atomic Energy Agency (IAEA) reported that it had discovered highly enriched uranium at one of Iran's nuclear facilities and complained that Iran had hidden parts of its nuclear program from inspectors. (The IAEA is the international organization responsible for ensuring that countries comply with their nuclear non-proliferation commitments.) Highly enriched uranium is not necessary for nuclear power, but is a critical component of nuclear weaponry. Although enriching uranium is not forbidden under the terms of the Nuclear Non-Proliferation Treaty (NPT), of which Iran is a signatory, it did suggest that Iran might be developing fissile nuclear material suitable for use in a nuclear bomb and flatly contradicts what the Iranian government had said on the issue.

Faced with the possibility of Iranian weapons of mass destruction, the United States argued that Iran should be brought immediately before the UN Security Council. However, Britain, France, and Germany (EU-3), along with the EU, opted to engage Iran in further dialog. In Tehran, in October 2003, they convinced Iran to agree to suspend its enrichment and sign an additional protocol to the NPT that would permit more thorough inspections of Iranian nuclear facilities. The "Tehran Agreement" saved Iran from the immediate threat of UN sanctions, opened the door to closer surveillance by the IAEA, and put the Iranian nuclear program on hold for the time being.

Iranian cooperation, however, was relatively short lived. Tensions between Iran and the IAEA continued over the course of 2004, and in September Iran again began enriching uranium. As a result, history repeated itself in the fall of 2004. The United States pressed for referral to the Security Council, while the E3/EU continued their diplomatic efforts. These efforts succeeded in defusing the immediate crisis. Iran agreed to suspend its enrichment program again by accepting European assistance in building a light water reactor (useful only for civilian energy purposes) and a resumption of the trade and investment talks that had faltered since 2003. Negotiations on the basis of this "Paris Agreement” began in December.

The European Union Center of Excellence of the University of North Carolina at Chapel Hill is funded by the European Union to advance knowledge and understanding of the EU and its member countries. 
The negotiations were complicated by the fact that Iran's internal political scene had begun to shift away from the reformists and back toward the conservatives. Parliamentary elections in 2004 yielded power to a conservative coalition. More significantly, in June 2005 the radical-conservative Mahmoud Ahmadinejad was elected President. President Ahmadinejad's populism, his frequent diatribes against Israel and his proud nationalism only further complicated negotiations with the international community ${ }^{i}$. In the end, the main division seemed to be the EU's insistence that Iran would have to agree to a permanent suspension of all enrichment activities, while Iran argued rather that it would provide objective guarantees that its fuel cycle would not be diverted to make nuclear weapons. After long delays, the EU-3 offered Iran a package of incentives in August 2005, the so-called "Framework for a Long-term Agreement". Moreover, for the first time, the EU-3 had secured the backing of the US for this package, which included the lifting of a US sanction on Iranian WTO entry and the sale of spare parts to Iranian civilian airliners. However, this had come at a considerable price, as the US had made its backing conditional on the permanent cessation of all enrichment activities by Iran. While experts remain divided over the substance of the package, Iran rejected the agreement on the basis that it could not consent to a permanent cessation of enrichment activities, portrayed as an infringement of its sovereign rights and was supported by moderates in the government and the wider population ${ }^{\text {ii }}$.

In December 2005 a new round of negotiations between Iran and the EU-3 ended in deadlock and in January 2006 Iran resumed uranium enrichment activities. In response, the EU-3 sought to ratchet-up pressure by agreeing to send the Iran file for the first time to the UN Security Council - a process that initiated the logic of sanctions. In response, Iran suspended its voluntary cooperation with the IAEA and accelerated its enrichment program. In the light of increasing tension, the EU-3 made yet another attempt to come to a compromise. Thus, the EU-3 succeeded in convincing the US, Russia and China (EU$3+3)$ to agree to a new package of incentives which was offered to Iran in June 2006. When it appeared that Iran was not interested in the new proposal, a first UN Security Council resolution was agreed, demanding an end to Iranian enrichment by the end of August 2006. Iran's failure to comply finally resulted in the beginning of a process to impose sanctions, a seemingly inevitable result given the frustrating circumstances.

How are we able to explain the failure of EU incentives after three years? At the end of a lengthy negotiation process, European incentives appeared too feeble to convince Iran to abandon its nuclear program. The sticking point in negotiations, time and again, has been the European demand for a permanent suspension of the enrichment process. Europe was unable and unwilling to compromise on this condition, as this would have led to the immediate withdrawal of US support. Indeed, on several occasions during the negotiations, Germany attempted to table proposals that would have left Iran with a limited enrichment capacity, only to be severely reprimanded by the US and its European partners. Iran's ultra-nationalistic government, on the other hand, was unwilling to accept any infringement on its "sovereign rights" to enrich uranium.

The European Union Center of Excellence of the University of North Carolina at Chapel Hill is funded by the European Union to advance knowledge and understanding of the EU and its member countries. 


\section{The Road to Sanctions}

With Iran's refusal to meet the August 2006 deadline set by the UN Security Council, the international community began to consider legal steps against Iran. However, it immediate became obvious that especially Russia and China were not yet prepared to take harsh measures against Iran. Lengthy negotiations followed, leading to the UN Security Council Resolution 1737 of 23 December 2006, which for the first time imposed economic sanctions on Iran. Watered down by Russia and China, UN sanctions were limited to a ban on the import and export of nuclear-related activities, and freezing the assets of several Iranian companies and individuals. The imposition of UN sanctions was paired with an offer by the IAEA for a sixty day grace period, during which the suspension of uranium enrichment would lead to an immediate lifting of sanctions. As this grace period expired, the UN passed Security Council Resolution 1747 in March 2007, intensifying the previous sanctions package. Sanctions were now extended to include arms exports and travel bans and further widened the number of organizations and individuals affected.

The imposition of UN sanctions irrevocably changed the dynamic of EU-3 negotiations with Iran. Nevertheless, the EU remained open to reengage with Iran throughout 2007, with the EU foreign policy-chief Javier Solana regularly meeting with Iranian negotiators. Moreover, UN sanctions seemed to have reached their limit by March 2007, with neither Russia nor China showing themselves willing to agree to a further tightening of sanctions. Frustrated with the lack of progress in negotiations and the stalemate at the UN, some European countries raised the specter of separate EU sanctions against Iran should the deadlock persist. Surprisingly the initiative for separate EU sanctions has been spearheaded by the new French government under Nicolas Sarkozy. Keen to shake off the anti-American reputation of the Chirac era, the new French government has distinguished itself with tough sounding rhetoric, foreign minister Bernard Kouchner even argued in summer 2007 that it was necessary to be prepared for war against Iran to round condemnation. So far, French and British pressure in the EU for separate EU sanctions have been rejected by a coalition of countries including Germany, Italy and Austria. They have remained firm in arguing that any new sanctions regime would have to be agreed at the UN and that separate EU sanctions would only serve to undermine the standing of the EU as a negotiator and also fail to provide new solutions.

\section{EU Trade with Iran}

\begin{tabular}{ccccc}
\hline Year & $\begin{array}{c}\text { Imports } \\
\text { (billion) }\end{array}$ & $\begin{array}{c}\text { EU share of } \\
\text { total imports }\end{array}$ & $\begin{array}{c}\text { Exports } \\
\text { (billion) }\end{array}$ & $\begin{array}{c}\text { EU share of } \\
\text { total exports }\end{array}$ \\
\hline 2002 & 5.615 & $41.86 \%$ & 8.237 & $22.76 \%$ \\
2003 & 6.953 & $41.14 \%$ & 10.011 & $23.81 \%$ \\
2004 & 8.217 & $42.67 \%$ & 11.873 & $23.85 \%$ \\
2005 & 11.449 & $41.04 \%$ & 12.902 & $24.37 \%$ \\
2006 & 14.126 & $33.45 \%$ & 11.191 & $23.94 \%$ \\
\hline
\end{tabular}

Source: Eurostat, August 2007

The European Union Center of Excellence of the University of North Carolina at Chapel Hill is funded by the European Union to advance knowledge and understanding of the EU and its member countries. 
What would the effects be of separate EU sanctions? Would they stand any chance of influencing Iranian behavior concerning nuclear proliferation? The effect of any separate EU sanctions on Iran would obviously much depend on the target and the extent of the sanctions regime. Overall the EU does indeed possess the capacity to considerably damage the Iranian economy through sanctions. Thus, in 2006 the EU accounted for approximately 33.5\% of Iran's €36.6 billion imports and 24\% of Iran's exports of $€ 53$ billion. This makes the EU Iran's main trading partner, holding $27.8 \%$ of total market share. It is followed by China with $12.3 \%$, Japan 9.8\%, South Korea $6.1 \%$ and Turkey, Unite Arab Emirates, South Africa, Russia and Singapore with between 2\% and 4\% each.

Given Europe's leading market position in Iran, EU trade sanctions would have a detrimental impact on the Iranian economy and in theory therefore represents a powerful diplomatic tool. However, as the case of Iraq showed, economic sanctions do not always produce the consequences intended and often damage the civilian population, rather than the government or political leadership. Moreover, European companies, already under pressure from Chinese competition in many places in the Middle East and Africa are reluctant to cede this traditional European markets to their Asian competitors. Their argument goes that sanctions would only lead to a replacement of European exports by Chinese and a commensurate reduction of European influence on this strategically important country. Moreover, with energy prices at a peak, nobody in Europe seems seriously to relish isolating one of the world's largest energy producers. Given these circumstances French and British proposals appeared more as an attempt to get into the good graces of the United States, rather than a serious attempt at the imposition of sanctions. Nevertheless by the end of 2007, and under U.S. pressure, a consensus seemed to be emerging in Europe that further sanction, whether at UN or EU level and even if only of a limited extent needed to be considered, in order to display Western resolve.

\section{The End of Iran's Nuclear Saga?}

In this situation, the publication of the latest United States National Intelligence Estimate (NIE) on 3 December 2007 seemed to seriously damage President Bush's intended course. The report, drawn from the material of the U.S. sixteen leading intelligence agencies, asserts with "high confidence" that Iran halted its nuclear-weapons program in 2003. While it concedes that "we do not know whether (Iran) currently intends to develop nuclear weapons", it reports "with moderate confidence that Tehran had not restarted its nuclear weapons program as of mid-2007.” Perhaps most significantly, the NIE report confirms that "the double approach chosen by the international community of incentives and measures from the United Nations Security Council was right”. Not surprisingly, the publication of the NIE report was celebrated as a major victory by the Iranian authorities and caused European intelligence agencies to re-check their analysis.

Despite the publication of the report, U.S. President George W. Bush has maintained that Iran remained a serious threat and refused to rule out the use of military force. EU leaders have shown themselves similarly cautious, with Javier Solana arguing that Europe would

The European Union Center of Excellence of the University of North Carolina at Chapel Hill is funded by the European Union to advance knowledge and understanding of the EU and its member countries. 
maintain its twin approach of dialog and pressure. Indeed, EU leaders have maintained that new sanctions were not off the table and would be discussed at an EU gathering in later January. However, in the light of these developments, it seems highly unlikely that sufficient support within the EU can be found to support a separate EU sanctions regime. Finally, support for sanction at the UN Security Council has also vanished, with Russia recently concluding a deal with Iran to finish the Bushehr nuclear reactor. In this situation, what is needed above all is a better understanding of Iranian nuclear intentions in the West. Arguably this will be much easier to achieve with a resumption of IAEA inspections. Europe's primary target should therefore be to steer its international partners towards a resumption of inspections, perhaps by once more revisiting its previous offers of incentives to Tehran, whilst simultaneously stepping up covert means to ascertain the intentions behind this troubling program.

i It should, however, be noted that in Iran the President only plays a secondary role in determining security issues, which is an area of responsibility reserved for Iran's Supreme religious leader.

ii Uranium enrichment is indeed allowed under the terms of the NPT.

The European Union Center of Excellence of the University of North Carolina at Chapel Hill is funded by the European Union to advance knowledge and understanding of the EU and its member countries. 